\title{
杉浦千登勢 学位論文審査要旨
}

主 査 渡 辺高 志

副主査 大 濱 栄 作

同 大 野 耕 策

\section{主論文}

Immunohistochemical expression of fibroblast growth factor (FGF) -2 in epilepsy-associated malformations of cortical development (MCDs)

(てんかん原性大脳皮質形成異常における線維芽細胞増殖因子 20 免疫組織化学的 発現)

(著者：杉浦千登勢、宮田元、上田麻奈美、大浜栄作、Harry V. Vinters、大野耕策) 平成20年 Neuropathology 第28巻 掲載予定 


\section{学 位 論 文 要 旨}

\section{Immunohistochemical expression of fibroblast growth factor (FGF)-2 in epilepsy-associated malformations of cortical development (MCDs) （てんかん原性大脳皮質形成異常における線維芽細胞増殖因子2の免疫組織 化学的発現)}

てんかん原性大脳皮質形成異常 (malformations of cortical development： MCDs）には、異形成性神経細胞（dysplastic neurons; DNs) やballoon cells (BCs) などの特徵的な異形細胞が出現する限局性皮質異形成（focal cortical dysplaisa:FCD) や結節性硬化症皮質結節〔tuberous sclerosis complex (TSC) -tubers）が知られている。線維芽細胞増殖因子（fibroblast growth factor；FGF）は細胞の増殖・遊走・分化および生存維持に関わる神経栄養因子 である。脳内の発現が確認されている10クラスのFGFのうち、FGF-2は発達時期 により脳内分布が変化する。てんかんモデル動物ではFGF-2が興奮性獲得やてん かん原性形成に関与寸ることが報告されている。筆者らは、MCDsの病態を解明 するために難治性てんかんを呈した脳組織におけるFGF-2の発現を免疫組織化 学的に検討した。

\section{方 法}

対象は、インフォームドコンセントが得られた難治性てんかん 12 症例の外科 的切除脳組織で、内訳は、FCD with BCs 4例、TSC-tubers 2例、FCD without BCs 3例、グリオーシスのみを呈した非異形成性皮質病変 3例である。これら脳組織 のパラフィン包埋切片を用い、リン酸化ニューロフィラメント (2F11)、非リン 酸化ニューロフィラメント (SMI311)、ビメンチン (V9)、glial fibrillary acidic protein (GFAP)、乏突起膠細胞転写因子2（01ig2）および FGF-2を一次 抗体とし、ポリマー標識法による免疫組織化学を行った。FGF-2免疫染色標本を 用いて、TSC-tubers群を除く3群におけるFGF-2陽性細胞の割合を算出し統計学 的に評価した。

\section{結 果}

BCsは、FCD with BCs群およびTSC-tubers群で見られ、GFAPが核や胞体に、 SMI311が一部の胞体に発現していたが、01ig2の発現はみられなかった。一方、 
DNsはFCD with BCs群、TSC-tubers群およびFCD without BCs群で見られ、SMI311 が胞体に強く発現していたが、GFAPや01ig2の発現は見られなかった。なお、FCD with BCs群およびTSC-tubers群の異形成性病変部に見られる01ig2陽性細胞は、 紡錘形ないし不整形の核を呈し、GFAPの共発現は見られなかった。

FGF-2の発現はBCsの胞体や核に認められた。FCD with BCs群およびTSC-tubers 群におけるDNsの胞体で弱い発現が見られたが、核での発現は見られなかった。 一方、FCD without BCs群のDNsには発現が見られなかった。全群で、反応性ア ストロサイトの核や胞体に強く発現していた。対照として用いた海馬硬化症例 の組織学的に正常な側頭葉新皮質部と白質部ではアストロサイトの主に核に強 く発現していた。FGF-2との二重染色では、GFAP陽性のBCs と反応性アストロサ イト、SMI311陽性のBCsで共発現が認められたが、01ig2陽性細胞での共発現は 認められなかった。各群におけるFGF-2陽性細胞の割合はFCD with BCs群で有意 に高かった。同様の結果はTSC-tubers群でも見られたが症例数が少ないため統 計学的解析は行わなかった。

\section{考 察}

FGF-2が神経細胞やグリア細胞への分化に重要な役割を演じていることや FGF-2欠損マウスでは大脳新皮質低形成が認められるとする報告から、FGF-2は 脳形成の各時期に特異的な作用を示す蛋白であることが推測される。今回初め て見出されたMCDsにおけるFGF-2の発現は、異形細胞の未熟性とMCDsの発生時期 を反映するものと考えられる。FGF-2は痤攣や脳損傷後にアストロサイトの核で 発現が増強し、興奮性シナプス増加作用や神経細胞保護作用を有することが報 告されている。今回見られたBCsにおけるFGF-2の発現様式は、アストロサイト に類似しており、BCsが反応性アストロサイトとともに異常興奮形成に積極的に 関与している可能性が示唆される。また、FGF-2の発現が増強している異形成性 病変部にみられる01ig2陽性細胞の形態的特徵から異形成性乏突起膠細胞の存 在も示唆される。

\section{結 論}

てんかん原性大脳皮質形成異常 (MCDs) における異形細胞はFGF-2を発現して いることを免疫組織化学的に初めて明らかにした。今回の結果から、MCDs各群 の発生時期の違い、および異形細胞は神経芽細胞や膠芽細胞の分化・成熟の異 常を反映することが示唆された。 